\title{
Reduction of hexavalent chromium by Ochrobactrum intermedium BCR400 isolated from a chromium-contaminated soil
}

\author{
B. Kavita - Haresh Keharia
}

Received: 20 September 2011/ Accepted: 13 November 2011/Published online: 29 November 2011

(C) The Author(s) 2011. This article is published with open access at Springerlink.com

\begin{abstract}
Hexavalent chromium-resistant Ochrobactrum intermedium BCR400 was isolated from chromium contaminated soil collected from Vadodara, Gujarat. It reduced $100 \mathrm{mg} \mathrm{Cr}(\mathrm{VI}) / \mathrm{L}$ completely in $52 \mathrm{~h}$ with initial $\mathrm{Cr}(\mathrm{VI})$ reduction rate of $1.98 \mathrm{mg} / \mathrm{L} / \mathrm{h}$. The $\mathrm{Cr}(\mathrm{VI})$ reduction rate decreased with increase in $\mathrm{Cr}(\mathrm{VI})$ concentration from 100 to $500 \mathrm{mg} / \mathrm{L}$. The addition of anthraquinone-2-sulphonic acid (AQS) to culture O. intermedium BCR400 significantly enhanced its chromium reduction rate. The activation energy of AQS-mediated $\mathrm{Cr}(\mathrm{VI})$ reduction $(120.69 \mathrm{KJ} /$ mol) was 1.1-fold lower than non-mediated $\mathrm{Cr}(\mathrm{VI})$ reduction. An increase in the activities of quinone reductase and chromate reductase in cells grown in presence of AQS/ $\mathrm{AQS}+\mathrm{Cr}(\mathrm{VI})$ suggests their role in reduction of $\mathrm{Cr}(\mathrm{VI})$ by $O$. intermedium. Both chromate reductase and quinone reductase activities were $\mathrm{FAD}$ independent, required $\mathrm{NADH}$ as reductant, displayed maximum activity at $\mathrm{pH}$ (7.0) and temperature $\left(30^{\circ} \mathrm{C}\right)$. Thus $\mathrm{Cr}(\mathrm{VI})$ bioremediation potential of $O$. intermedium can be enhanced by augmentation of system with AQS as redox mediator.
\end{abstract}

Keywords $\mathrm{Cr}(\mathrm{VI})$ reduction $\cdot$ Biolog $\cdot$ Redox mediators · Chromate reductase $\cdot$ Quinone reductase

\section{Introduction}

Chromium $(\mathrm{Cr})$ is one of the most widely used metals in variety of industrial processes such as steel production, dye manufacturing, wood preservation, chrome plating and

B. Kavita $\cdot$ H. Keharia $(\square)$

BRD School of Biosciences, Sardar Patel University,

Vadtal Road, Vallabh Vidyanagar 388120, Gujarat, India

e-mail: haresh970@gmail.com leather tanning (Agarwal et al. 2008). Industrial effluents containing chromium compounds without proper treatment released directly or indirectly into natural water resources represent the major anthropogenic sources of $\mathrm{Cr}$ contamination of pristine environments. Chromium mainly exists as two stable oxidation states, $\mathrm{Cr}(\mathrm{VI})$ and $\mathrm{Cr}(\mathrm{III})$, other oxidation states of $\mathrm{Cr}$ viz., $+\mathrm{V},+\mathrm{IV}$ and $+\mathrm{II}$ are less stable and thus insignificant. $\mathrm{Cr}(\mathrm{VI})$ and $\mathrm{Cr}(\mathrm{III})$ differ completely in their physiochemical properties and toxicity (Ishibashi et al. 1990). Cr(VI) being highly toxic, mutagenic and carcinogenic (Costa 1997; Nishioka 1975; Wang et al. 1990) has been listed as one of the 17 chemicals posing greatest threat to humans by United States Environmental Protection Agency (USEPA) (McCullough et al. 1999). In-vivo, $\mathrm{Cr}(\mathrm{VI})$ due to the oxidizing activity results in generation of reactive oxygen species (ROS), which in turn causes oxidative damage to DNA, proteins and lipids (Cervantes et al. 2001). In contrast, $\mathrm{Cr}$ (III) being sparingly soluble, is also oxidatively more stable and thus less toxic in comparison to $\mathrm{Cr}$ (VI) (Dinakarpandian et al. 2004). Thus, biotransformation of $\mathrm{Cr}(\mathrm{VI})$ to the less toxic $\mathrm{Cr}(\mathrm{III})$ is considered as a feasible strategy for the remediation of $\mathrm{Cr}(\mathrm{VI})$ pollution worldwide (Diaz et al. 2008; Williams and Silver 1984). Effective physico-chemical methods have been developed for reduction of $\mathrm{Cr}(\mathrm{VI})$ to $\mathrm{Cr}(\mathrm{III})$, however, they suffer from limitations of use of chemicals and sludge generation with subsequent disposal problems. Biological processes on other hand are considered eco-friendly and less expensive (Losi et al. 1994; Saleh et al. 1989; Shannon and Unterman 1993). Several reports on microbial biotransformation of $\mathrm{Cr}(\mathrm{VI})$ to less toxic $\mathrm{Cr}(\mathrm{III})$ through direct enzymatic reaction or indirectly through metabolites exist in literature (Saleh et al. 1989; Puzon et al. 2002). The enzymatic chromate reaction occurs both in anaerobic as well as aerobic conditions (Cervantes et al. 2001). The anaerobic 
chromate reduction occurs in presence of membrane bound enzymes (Diaz et al. 2008). The $\mathrm{Cr}$ (VI) reducing activity in Escherichia coli, Shewanella putrefaciens and Enterobacter cloacae strains grown under anaerobic condition have been found to be located in membrane preparation (Myers et al. 2000; Shen and Wang 1993; Wang et al. 1990). In contrast, chromate reductases have been localized as soluble cytosolic proteins in most aerobic chromate reducing bacteria (Garbisu et al. 1998; Ishibashi et al. 1990; Puzon et al. 2002). Several oxidoreductases with unrelated metabolic functions have also been reported to catalyse $\mathrm{Cr}$ (VI) reduction in bacteria. Examples of such enzymes include, quinone reductases, iron reductases, nitro-reductases, flavin reductases and several NADH/NAD(P)H-dependent reductases of unknown function (Clark 1994; Gonzalez et al. 2003, 2005; Kwak et al. 2003; Mazoch et al. 2004; Suzuki et al. 1992). Gonzalez et al. (2005) demonstrated that the primary function of $E$. coli chromate reductase ( $\mathrm{chr}$ $\mathrm{R})$ was quinone reduction rather than chromate reduction.

Most of the studies reported on $\mathrm{Cr}(\mathrm{VI})$ reduction have concentrated on isolation, characterization and application of Cr(VI) reducing bacteria. Rehman et al. (2008) reported Bacillus sp. ev3 which was found to reduce $91 \%$ of $100 \mathrm{mg}$ $\mathrm{Cr}(\mathrm{VI}) / \mathrm{L}$ after $96 \mathrm{~h}$ in growth medium. He et al. (2009) isolated Ochrobactrum sp. CsCr-3 which was found to reduce $100 \mathrm{mg} \mathrm{Cr}(\mathrm{VI}) / \mathrm{L}$. Since bioremediation strategy of $\mathrm{Cr}(\mathrm{VI})$ involves its reduction to $\mathrm{Cr}$ (III), it would be apt to employ redox mediators to accelerate the process of electron transfer to Cr(VI). Recently, Zee and Cervantes (2009) have reviewed the impact of several quinone and viologen compounds (known to act as redox mediators) on redox biotransformation of contaminants. The redox mediators have been shown to accelerate the reductive degradation rate of several electron withdrawing recalcitrants while in certain instances such as Fe(III), U(VI), Tc(VII) they have even been required as prerequisites for initiation of their biodegradation (Fredrickson et al. 2006). Recently, Liu et al. (2010) reported that quinone redox mediator (lawsone) enhanced the rate of $\mathrm{Cr}(\mathrm{VI})$ reduction of by resting cells of $E$. coli, significantly.

This paper describes the studies on $\mathrm{Cr}(\mathrm{VI})$ reduction by O. intermedium BCR400, isolated from landfill site of chemical industry near Vadodara, Gujarat, India. Furthermore, we have investigated the role of anthraquinone 2-sulphonate (AQS) on reduction of $\mathrm{Cr}(\mathrm{VI})$ by $O$. intermedium BCR400 which has not been reported previously.

\section{Materials and methods}

Chemicals

Luria Bertani (LB) broth and redox mediators (namely, Anthraquinone sulphonate, Ethyl viologen, Benzyl viologen and Methyl viologen) were purchased from HiMedia Laboratories Ltd, Mumbai, India. Diphenyl carbazide and potassium dichromate $\left(\mathrm{K}_{2} \mathrm{Cr}_{2} \mathrm{O}_{7}\right)$ were procured from Qualigens, India.

Bacterial strain, identification and growth conditions

The bacterial strain, BCR400 tolerant to $\mathrm{Cr}(\mathrm{VI})$ was isolated from a long-term chromium polluted soil collected from landfill sites of Gorwa industrial zone $\left(22^{\circ} 19^{\prime} 0^{\prime \prime}\right.$ North, $73^{\circ} 10^{\prime} 0^{\prime \prime}$ East), Vadodara, Gujarat, India by enrichment culture technique. The culture was grown on LB agar plates (containing; Tryptone $10 \mathrm{~g} / \mathrm{L}$, Yeast Extract $5 \mathrm{~g} / \mathrm{L}, \mathrm{NaCl} 10 \mathrm{~g} / \mathrm{L})$ amended with $100 \mathrm{mg} \mathrm{Cr}(\mathrm{VI}) / \mathrm{L}$. The $\mathrm{K}_{2} \mathrm{Cr}_{2} \mathrm{O}_{7}$ was used as source of $\mathrm{Cr}(\mathrm{VI})$ in all experiments.

BCR400 was identified using MicroLog 3 bacterial identification system employing GN2 and GEN III plates following the procedure recommended by the manufacturer (Biolog Inc., USA). Additionally, nucleotide sequence of 16S rRNA gene from BCR400 was also determined. The analysis of the nucleotide sequence was done using Blast-n tool at NCBI (http://blast.ncbi.nlm.nih.gov/Blast.cgi). The phylogenetic tree was constructed by the neighbour-joining method using MEGA version 4.0 (Tamura et al. 2007).

\section{$\mathrm{Cr}(\mathrm{VI})$ reduction by isolate $O$. intermedium $\mathrm{BCR} 400$}

The $250 \mathrm{~mL}$ Erlenmeyer flasks containing $100 \mathrm{~mL} \mathrm{LB}$ broth amended with $\mathrm{Cr}(\mathrm{VI})(100-500 \mathrm{mg} / \mathrm{L})$ were inoculated with overnight grown cells of $O$. intermedium $\left(A_{660 \mathrm{~nm}} \approx 1.0\right)$. Uninoculated controls were used to compare abiotic $\mathrm{Cr}(\mathrm{VI})$ reduction during experiment. The inoculated cultures along with un-inoculated controls were incubated at $37{ }^{\circ} \mathrm{C}$ with shaking (150 rpm on orbital shaker) and $1 \mathrm{~mL}$ samples were withdrawn at regular time intervals to monitor growth and $\mathrm{Cr}(\mathrm{VI})$ reduction.

\section{Mediated $\mathrm{Cr}(\mathrm{VI})$ reduction by $O$. intermedium BCR400 in batch mode}

LB broth amended with $\mathrm{Cr}(\mathrm{VI})$ (100 mg/L) was supplemented with redox mediators; AQS, ethyl viologen, methyl viologen and benzyl viologen to a final concentration of $1 \mathrm{mM}$. The $\mathrm{Cr}(\mathrm{VI})$ reduction was initiated after inoculation of culture flasks with $O$. intermedium BCR400. The $\mathrm{Cr}(\mathrm{VI})$ reduction as well as growth was monitored from samples withdrawn at different time intervals.

Control experiments were performed in the same manner except that no redox mediator was added to Luria Bertani broth.

Mediated $\mathrm{Cr}(\mathrm{VI})$ reduction by $O$. intermedium BCR400 in presence of different concentration of AQS was studied wherein, Luria Bertani broth amended with $\mathrm{Cr}(\mathrm{VI})(100 \mathrm{mg} /$ 
L) was supplemented with AQS in the concentration range 0-5 mM. Cr(VI) reduction as well as growth was monitored from samples withdrawn at different time intervals.

Effect of temperature on AQS-mediated $\mathrm{Cr}(\mathrm{VI})$ reduction

The AQS-mediated and non-mediated $\mathrm{Cr}(\mathrm{VI})$ reduction was determined at various incubation temperatures $\left(25-40{ }^{\circ} \mathrm{C}\right)$. The $\mathrm{Cr}(\mathrm{VI})$ amended LB broth supplemented either with or without $1 \mathrm{mM}$ AQS was inoculated with overnight grown culture of $O$. intermedium $\mathrm{BCR} 400$ and incubated at various temperatures $\left(25-40{ }^{\circ} \mathrm{C}\right)$. The samples were withdrawn at regular time intervals to monitor residual $\mathrm{Cr}(\mathrm{VI})$.

The activation energy of the AQS-mediated and nonmediated $\mathrm{Cr}(\mathrm{VI})$ reduction by $O$. intermedium $\mathrm{BCR} 400$ was calculated by employing Arrhenius equation as follows:

$\ln k=-E a / R T+\ln A o$

where $k$ is the first-order rate constant $\left(\mathrm{h}^{-1}\right), E a$ is activation energy, $R$ is the gas constant $\left(\mathrm{KJ} \mathrm{mol}^{-1}\right), T$ is the temperature (kelvin) and $A o$ is constant called the Frequency factor. Value of $E$ a can be determined from the Slope $(-E a / R)$ of $\ln k$ versus $1 / T$ plot (Santos et al. 2004).

Preparation of cell-free lysate

Ochrobactrum intermedium BCR400 was grown in $200 \mathrm{~mL}$ Luria Bertani broth for $24 \mathrm{~h}$ at $30{ }^{\circ} \mathrm{C}$. The cell pellet obtained upon centrifugation $(8,603 \times g$ for $15 \mathrm{~min})$ was resuspended in $3 \mathrm{~mL}$ of phosphate buffer $(100 \mathrm{mM}$, $\mathrm{pH}$ 7.0). The resuspended cells were disrupted by sonication under ice bath (Sonics \& Materials, Inc., USA) for 15 min (with $9 \mathrm{~s}$ on followed by $1 \mathrm{~s}$ off pulses) by supplying power at $35 \%$ amplitude. The resultant homogenate was centrifuged at $8,603 \times g$ for $30 \mathrm{~min}$ at $4{ }^{\circ} \mathrm{C}$ to remove cell debris and the clear supernatant was used as cell-free lysate for enzyme assays.

$\mathrm{pH}$ and temperature optima of chromate and quinone reductase activities

The influence of $\mathrm{pH}$ and temperature on chromate and quinone reductase activity was assessed. For determination of optimal $\mathrm{pH}$, the quinone and chromate reductase activity was assayed at $30{ }^{\circ} \mathrm{C}$ using $50 \mathrm{mM}$ sodium acetate buffer (pH 5-5.5), potassium phosphate buffer $(\mathrm{pH} \mathrm{6.0-7.5)} \mathrm{and}$ Tris-HCl buffer (7.5-8.5).

Optimal temperature was determined wherein the chromate and quinone reductase activity was assayed at various temperatures (ranging $20-50{ }^{\circ} \mathrm{C}$ ) using thermostatic cuvette holder (ELICO DL 198 biospectrophotometer, Hyderabad, India)

\section{Analytical methods}

Enzyme assays

The NADH: quinone reductase and chromate reductase were assayed as described previously by Puzon et al. (2002). Briefly, quinone and chromate reductase activity was assayed spectrophotometrically at constant temperature of $30{ }^{\circ} \mathrm{C}$ by following the oxidation of NADH at $340 \mathrm{~nm}$ (Molar absorption coefficient $6.22 \mathrm{mM}^{-1} \mathrm{~cm}^{-1}$ ). The reaction was initiated by addition of cell-free lysate to reaction mixture containing $50 \mathrm{mM}$ phosphate buffer $(\mathrm{pH}$ 6.0) and $0.1 \mathrm{mM}$ substrate (Lawsone as quinone reductase substrate and $\mathrm{K}_{2} \mathrm{Cr}_{2} \mathrm{O}_{7}$ as chromate reductase substrate).

One unit of enzyme activity was defined as the amount of enzyme required for oxidation of $1 \mu$ mole of NADH per min under standard assay conditions (Santos et al. 2004).

\section{Quantification of growth and $\mathrm{Cr}(\mathrm{VI})$}

Growth of $O$. intermedium BCR400 was monitored turbidometrically. The cell pellet obtained upon centrifugation of $1 \mathrm{~mL}$ of culture was resuspended in $1 \mathrm{~mL}$ distilled water and its absorbance was measured at $660 \mathrm{~nm}$. The turbidometric measurements were then converted to dry biomass $(\mathrm{g} / \mathrm{L})$ using a correlation curve between absorbance of cell suspension $(660 \mathrm{~nm})$ and gravimetric biomass $(\mathrm{g} / \mathrm{L})$ measurement determined for $O$. intermedium BCR400 in our laboratory. The $\mathrm{Cr}(\mathrm{VI})$ concentration in the cell-free supernatant was measured using Diphenylcarbazide (DPC) reagent as described by Ishibashi et al. (1990). Briefly, the hexavalent chromium containing samples (in the range $1-10 \mu \mathrm{g}$ ) were acidified by adding $330 \mu \mathrm{L}$ of $6 \mathrm{~N}$ sulphuric acid. To this acidified solution of the hexavalent chromium, DPC was added at concentration of $0.25 \%$ and final volume was made up to $10 \mathrm{~mL}$. The mixture was incubated for $10 \mathrm{~min}$ at room temperature and the colour of DPC: $\mathrm{Cr}(\mathrm{VI})$ complex was measured by reading the absorbance at $540 \mathrm{~nm}$.

Protein estimation

The protein concentration of the cell-free extract (CFE) were estimated using Folin-phenol reagent by reading absorbance at $720 \mathrm{~nm}$, following the principle of Lowry et al. (1951).

\section{Results and discussion}

Isolation and identification of BCR400

A hexavalent chromium-reducing bacterial strain designated as BCR400 was isolated from the $\mathrm{Cr}(\mathrm{VI})$ 
contaminated soil collected from the landfill site of chemical industry in Gorwa GIDC of Vadodara, Gujarat, India. The isolate BCR400 was found to be motile, gram negative, short rod-shaped, possessed oxidase and catalase activities. On the basis of the carbon substrate utilization pattern employing GN2 as well as GENIII plates of BioLog, USA isolate BCR400 was identified as $O$. intermedium with similarity index of 0.74 and $99 \%$ probability. The identity of BCR400 was further confirmed by its $16 \mathrm{~S}$ rRNA gene nucleotide sequence which also showed $99 \%$ identity to $O$. intermedium. (Accession number: JN033212). The phylogenetic relationship of the strain BCR400 with other related bacterial strains are presented in Fig. 1.

Ochrobactrum intermedium belongs to $\alpha$-proteobacteria subclass and representatives of this taxa have been isolated previously from chromium contaminated soils, by several researchers world-wide (He et al. 2009; Ozdemir et al. 2003; Sultan and Hasnain 2007; Thacker and Madamwar 2005). $O$. intermedium BCR400 exhibited growth up to $500 \mathrm{mg}$ $\mathrm{Cr}(\mathrm{VI}) / \mathrm{L}$. The optimal temperature and $\mathrm{pH}$ for growth was found to be $37^{\circ} \mathrm{C}$ and $\mathrm{pH} 7.0$, respectively (Data not shown).

Time-course of $\mathrm{Cr}(\mathrm{VI})$ reduction by $O$. intermedium BCR400

Figure 2 shows that after a lag of $30 \mathrm{~min}$ growth and $\mathrm{Cr}(\mathrm{VI})$ reduction initiated simultaneously in an agitated batch culture of $O$. intermedium BCR400. The complete reduction of $112 \mathrm{mg} \mathrm{Cr}(\mathrm{VI}) / \mathrm{L}$ occurred within $72 \mathrm{~h}$ of incubation with initial reduction rate of $1.98 \mathrm{mg} \mathrm{Cr}(\mathrm{VI}) / \mathrm{L} /$ h. Thus, O. intermedium BCR400 not only showed resistance to $\mathrm{Cr}(\mathrm{VI})$ but also possessed ability to reduce $\mathrm{Cr}(\mathrm{VI})$, which is in agreement with report on $O$. tritici strain 5 bvl1 by Branco et al. (2004). The resting cells of $O$. intermedium BCR400 did not show any significant reduction of $\mathrm{Cr}(\mathrm{VI})$. The growth associated $\mathrm{Cr}(\mathrm{VI})$ reduction suggests the role of actively metabolizing cells in $\mathrm{Cr}(\mathrm{VI})$ reduction.

Effect of initial $\mathrm{Cr}(\mathrm{VI})$ concentration on growth and $\mathrm{Cr}(\mathrm{VI})$ reduction by $O$. intermedium BCR400

Ochrobactrum intermedium BCR400 was able to grow up to $500 \mathrm{mg} \mathrm{Cr}(\mathrm{VI}) / \mathrm{L}$, while growth rate was found to decrease with increasing $\mathrm{Cr}(\mathrm{VI})$ concentration. The initial $\mathrm{Cr}(\mathrm{VI})$ reduction rate was found to increase up to $100 \mathrm{mg}$ $\mathrm{Cr}(\mathrm{VI}) / \mathrm{L}$ without influencing the $\mathrm{Cr}(\mathrm{VI})$ reduction efficiency. However, further increase in $\mathrm{Cr}(\mathrm{VI})$ concentration up to $500 \mathrm{mg} / \mathrm{L}$, negatively affected initial $\mathrm{Cr}(\mathrm{VI})$ reduction rate as well as extent of $\mathrm{Cr}(\mathrm{VI})$ reduction by $O$. intermedium BCR400 (Table 1). The decrease in amount of biomass produced with increasing $\mathrm{Cr}(\mathrm{VI})$ concentration may be attributed to consumption of increasing amount of reducing power of cell towards reductive detoxification of Cr(VI) (Branco et al. 2004; Megharaj et al. 2003). This means, electrons generated by oxidation of organic carbon sources which otherwise would be utilized for biosynthesis of cell components, seems to be diverted towards $\mathrm{Cr}$ (VI) reduction, thus slowing down growth (Sultan and Hasnain 2007). Similar observations on decrease in $\mathrm{Cr}(\mathrm{VI})$ reduction rate with increasing concentration of $\mathrm{Cr}(\mathrm{VI})$ have been reported by several researchers using different bacterial cultures (Garbisu et al. 1998; Megharaj et al. 2003; Sultan and Hasnain 2006).

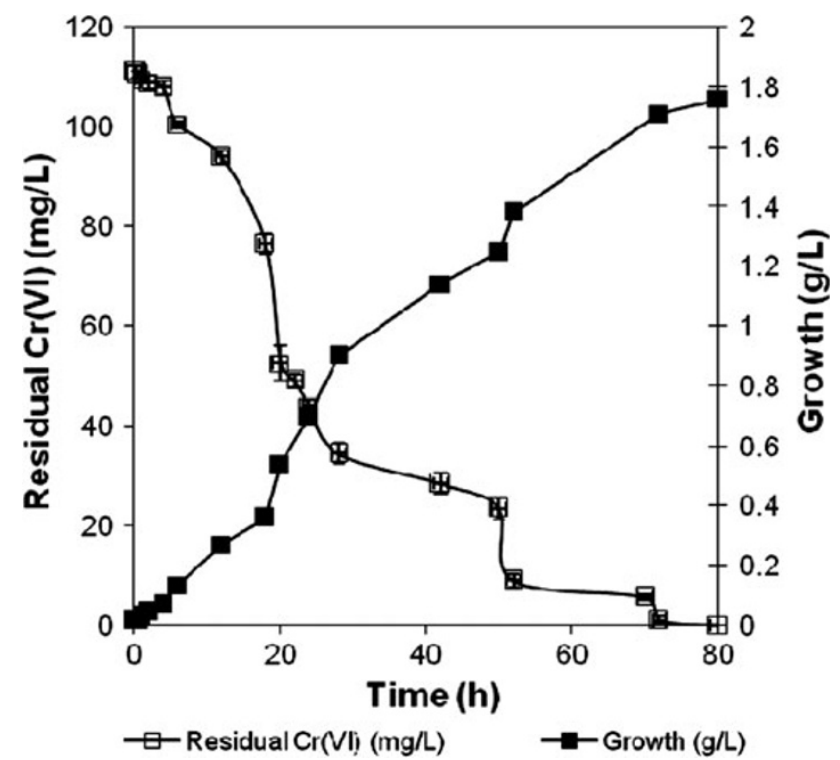

Fig. $2 \mathrm{Cr}(\mathrm{VI})$ reduction and growth profile of $O$. intermedium BCR400 in Luria Bertani broth amended with $100 \mathrm{mg} \mathrm{Cr}(\mathrm{VI}) / \mathrm{L}$
Fig. 1 Phylogenetic affiliation based on 16S rRNA gene sequence comparisons over 1,406 nucleotides showing the relationship between members of family Brucellaceae and isolate BCR400. The values at nod represent percentage of 1,000 bootstrap replicates. Numbers in bracket represents GenBank accession numbers

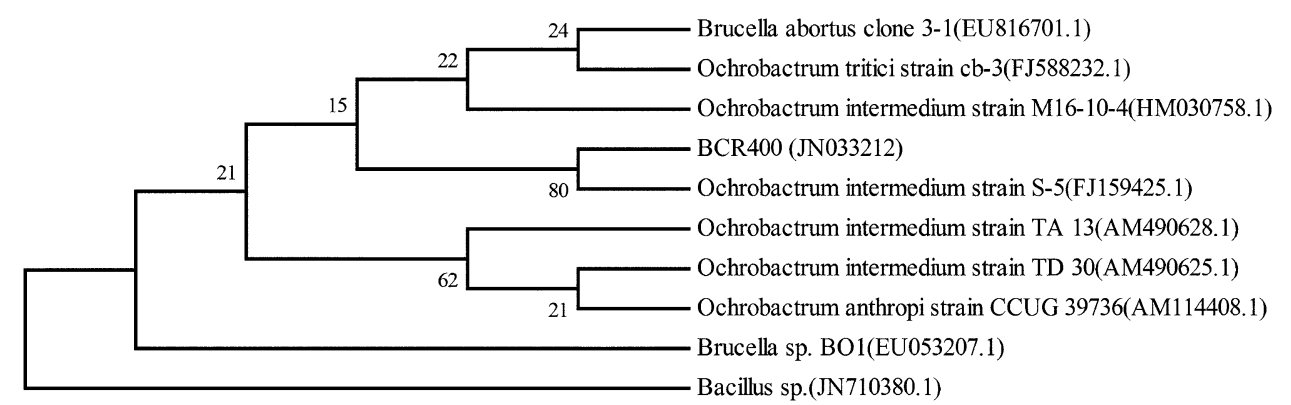


Table 1 Effect on initial $\mathrm{Cr}(\mathrm{VI})$ concentration (50-500 $\mathrm{mg} / \mathrm{L})$ on $\mathrm{Cr}(\mathrm{VI})$ reduction and growth of $O$. intermedium BCR400

\begin{tabular}{lcccc}
\hline $\begin{array}{l}\text { Initial Cr(VI) } \\
(\mathrm{mg} / \mathrm{L})\end{array}$ & $\begin{array}{l}\mathrm{Cr}(\mathrm{VI}) \text { reduction } \\
(\mathrm{mg} / \mathrm{L})\end{array}$ & $\begin{array}{l}\text { Initial Cr(VI) reduction rate } \\
(\mathrm{mg} / \mathrm{L} / \mathrm{h})\end{array}$ & $\begin{array}{l}\text { Maximum biomass } \\
(\mathrm{g} / \mathrm{L})\end{array}$ & $\begin{array}{l}\text { Growth rate }(\mathrm{g} / \\
\mathrm{L} / \mathrm{h})\end{array}$ \\
\hline 50 & $48.15 \pm 2.61$ & $1.29 \pm 0.148$ & $1.71 \pm 0.001$ & $0.0239 \pm 0.002$ \\
100 & $99 \pm 4.24$ & $1.98 \pm 0.034$ & $1.38 \pm 0.002$ & $0.0206 \pm 0.001$ \\
200 & $140 \pm 8.48$ & $1.20 \pm 0.118$ & $1.29 \pm 0.001$ & $0.0196 \pm 0.001$ \\
300 & $131.5 \pm 6.36$ & $0.97 \pm 0.002$ & $0.93 \pm 0.002$ & $0.0132 \pm 0.003$ \\
400 & $125 \pm 5.65$ & $0.844 \pm 0.006$ & $0.012 \pm 0.0003$ & $0.009 \pm 0.0007$ \\
500 & $127 \pm 0$ & $0.730 \pm 0.034$ & $0.012 \pm 0.0002$ & $0.007 \pm 0.0005$ \\
\hline
\end{tabular}

Effect of redox mediators on the $\mathrm{Cr}(\mathrm{VI})$ reduction by $O$. intermedium BCR400

Inclusion of low molecular weight redox mediator along with the metal is emerging as general approach to enhance bacterial reduction of multivalent metal ions (Bond and Lovley 2002; Lovley et al. 1998, 1999). In the present study, AQS, ethyl viologen, methyl viologen and benzyl viologen at $1 \mathrm{mM}$ concentration were included as redox mediator as they have been reported to act as potential redox mediator in the biotransformation of recalcitrant pollutants like sulphonated azo dye, iron, 2,4 dichlorophenoxy acetic acid and carbon tetra chloride (Bond and Lovley 2002; Ling et al 2009; Maithreepala and Doong 2009; Wang et al. 2009). O. intermedium BCR400 exhibited higher initial $\mathrm{Cr}(\mathrm{VI})$ reduction rate in presence of $1 \mathrm{mM}$ AQS, ethyl and methyl viologen (Table 2). In presence of $1 \mathrm{mM}$ AQS, O. intermedium BCR400 reduced $\mathrm{Cr}(\mathrm{VI})$ at 1.4 -fold higher rate $(2.88 \mathrm{mg} \mathrm{Cr}(\mathrm{VI}) / \mathrm{L} / \mathrm{h})$ than in absence of any redox mediators $(1.98 \mathrm{mg} \mathrm{Cr}(\mathrm{VI}) / \mathrm{L} / \mathrm{h})$.

Anthraquinone 2-sulphonate has been reported as powerful mediator for reductive biotransformation of several organic recalcitrants (Liu et al. 2010; Zee and Cervantes 2009). Although ethyl and methyl viologen also enhanced $\mathrm{Cr}$ (VI) reduction rate, they were found to inhibit growth of O. intermedium BCR400 (Table 2). Benzyl viologen severely inhibited the growth of $O$. intermedium BCR400.

Quinones are known for their potential role as redox centres in humic acid and therefore the $\mathrm{Cr}(\mathrm{VI})$ reduction rates in presence of AQS may attributed to their electron shuttling ability between $O$. intermedium BCR400 and $\mathrm{Cr}(\mathrm{VI})$. Zee and Cervantes (2009) suggested that the oxidation reduction potential of any mediator should not be much lower than $-0.320 \mathrm{~V}$, which is the lowest oxidation reduction potential of cofactor (NADPH) in the cell otherwise it would not be reduced significantly. Hence, the transfer of electrons from AQS to $\mathrm{Cr}(\mathrm{VI})$ seems to be thermodynamically favourable phenomenon as the standard redox potential $\left(E^{\circ}\right)$ of AQS is $-0.218 \mathrm{~V}$, which is significantly lower than the redox potential of $\mathrm{CrO}_{4}{ }^{2-}$ $(1.28 \mathrm{~V})$ and higher than $-0.320 \mathrm{~V}$. According to the above hypothesis, the poor mediating ability of ethyl viologen and methyl viologen may be explained by their much lower oxidation reduction potential $(-0.480$ and $-0.440 \mathrm{~V}$, respectively) than $-0.320 \mathrm{~V}$.

\section{Effect of AQS concentration on $\mathrm{Cr}(\mathrm{VI})$ reduction}

The optimum AQS:Cr(VI) ratio for $\mathrm{Cr}(\mathrm{VI})$ reduction by $O$. intermedium $\mathrm{BCR} 400$ was determined by varying the concentration of AQS while maintaining $\mathrm{Cr}(\mathrm{VI})$ concentration constant. It is clearly evident from Table 3, that initial $\mathrm{Cr}(\mathrm{VI})$ reduction rate of $O$. intermedium $\mathrm{BCR} 400$ increased with increase in AQS concentration from 0.1 to $1.0 \mathrm{mM}$. Further increase in AQS concentration to $2 \mathrm{mM}$ caused decrease in initial $\mathrm{Cr}(\mathrm{VI})$ reduction rate as well as growth of $O$. intermedium BCR400. The lower $\mathrm{Cr}(\mathrm{VI})$ reduction rate at suboptimal AQS concentrations may be explained by distribution of electrons between AQS-mediated reduction and direct $\mathrm{Cr}(\mathrm{VI})$ reduction. On the other hand, higher AQS concentrations $(2 \mathrm{mM})$ itself may be inhibitory to cell growth thus negatively influencing $\mathrm{Cr}(\mathrm{VI})$ reduction (Ling et al. 2009). This is because at higher AQS concentrations, the accumulation of reduced $\mathrm{AQS}\left(\mathrm{AQH}_{2} \mathrm{~S}\right)$,
Table 2 Effect of redox mediators on $\mathrm{Cr}(\mathrm{VI})$ reduction and growth of $O$. intermedium BCR400

\begin{tabular}{|c|c|c|c|c|}
\hline $\begin{array}{l}\text { Redox mediators } \\
(1 \mathrm{mM})\end{array}$ & $\begin{array}{l}\mathrm{Cr}(\mathrm{VI}) \text { reduction } \\
(\mathrm{mg} / \mathrm{L})\end{array}$ & $\begin{array}{l}\text { Initial } \mathrm{Cr}(\mathrm{VI}) \text { reduction rate } \\
(\mathrm{mg} / \mathrm{L} / \mathrm{h})\end{array}$ & Biomass (g/L) & $\begin{array}{l}\text { Initial growth rate } \\
(\mathrm{g} / \mathrm{L} / \mathrm{h})\end{array}$ \\
\hline None & $99.5 \pm 0.353$ & $1.98 \pm 0.034$ & $1.01 \pm 0.001$ & $0.038 \pm 0.0001$ \\
\hline AQS & $99.25 \pm 1.06$ & $2.9 \pm 0.123$ & $1.35 \pm 0.010$ & $0.052 \pm 0.0021$ \\
\hline Ethyl Viologen & $102 \pm 2.3$ & $2.12 \pm 0.062$ & $0.825 \pm 0.006$ & $0.022 \pm 0.0003$ \\
\hline Methyl Viologen & $103 \pm 4.7$ & $2.14 \pm 0.048$ & $0.768 \pm 0.011$ & $0.021 \pm 0.0003$ \\
\hline Benzyl Viologen & $60.87 \pm 6.9$ & $0.85 \pm 0.097$ & $0.047 \pm 0.003$ & $0.0012 \pm 0.00008$ \\
\hline
\end{tabular}


Table 3 Effect on AQS concentration $(0-2.0 \mathrm{mM})$ on $\mathrm{Cr}(\mathrm{VI})$ reduction and growth of O. intermedium BCR400

\begin{tabular}{lcccl}
\hline $\begin{array}{l}\mathrm{AQS} \\
(\mathrm{mM})\end{array}$ & $\begin{array}{l}\mathrm{Cr}(\mathrm{VI}) \text { reduction } \\
(\mathrm{mg} / \mathrm{L})\end{array}$ & $\begin{array}{l}\text { Initial Cr(VI) reduction rate } \\
(\mathrm{mg} / \mathrm{L} / \mathrm{h})\end{array}$ & $\begin{array}{l}\text { Biomass }(\mathrm{g} / \mathrm{L}) \\
\text { Initial growth rate }(\mathrm{g} / \\
\mathrm{L} / \mathrm{h})\end{array}$ \\
\hline 0 & $99.5 \pm 0.353$ & $1.98 \pm 0.0$ & $1.01 \pm 0.001$ & $0.038 \pm 0.0001$ \\
0.1 & $81.2 \pm 3.46$ & $1.49 \pm 0.0618$ & $0.993 \pm 0.0127$ & $0.029 \pm 0.0020$ \\
0.2 & $96.85 \pm 1.62$ & $1.72 \pm 0.0290$ & $1.04 \pm 0.0063$ & $0.030 \pm 0.0023$ \\
0.5 & $97.5 \pm 0.707$ & $2.2 \pm 0.141$ & $1.08 \pm 0.0$ & $0.031 \pm 0.0026$ \\
0.75 & $98.8 \pm 0.21$ & $2.43 \pm 0.0094$ & $1.22 \pm 0.003$ & $0.035 \pm 0.002$ \\
1.0 & $99.25 \pm 1.06$ & $2.9 \pm 0.123$ & $1.35 \pm 0.010$ & $0.052 \pm 0.0021$ \\
1.5 & $99.02 \pm 1.87$ & $2.61 \pm 0.022$ & $1.26 \pm 0.0013$ & $0.037 \pm 0.0011$ \\
2.0 & $83 \pm 1.41$ & $1.6 \pm 0.141$ & $0.939 \pm 0.042$ & $0.027 \pm 0.0010$ \\
\hline
\end{tabular}

Table 4 Quinone and chromate reductase activities (U/mg) of $O$. intermedium BCR400 grown in Luria Bertani (LB) broth amended with either $\mathrm{Cr}(\mathrm{VI})$ or AQS or both $\mathrm{Cr}(\mathrm{VI})$ and AQS

\begin{tabular}{lcc}
\hline Growth medium & \multicolumn{2}{c}{ Enzyme Activity $(\mathrm{U} / \mathrm{mg})$} \\
\cline { 2 - 3 } & Quinone reductase & Chromate reductase \\
\hline $\mathrm{LB}$ & $0.0063 \pm 0.0010$ & $0.0042 \pm 0.0001$ \\
$\mathrm{LB}+\mathrm{Cr}(\mathrm{VI})$ & $0.0139 \pm 0.0028$ & $0.013 \pm 0.00018$ \\
$\mathrm{LB}+\mathrm{AQS}$ & $0.026 \pm 0.004$ & $0.016 \pm 0.0005$ \\
$\mathrm{LB}+\mathrm{AQS}+\mathrm{Cr}(\mathrm{VI})$ & $0.025 \pm 0.0036$ & $0.020 \pm 0.00054$ \\
\hline
\end{tabular}

in absence or limiting concentration of suitable electron acceptor, would transfer electrons to $\mathrm{O}_{2}$, resulting in generation of ROS and thereby causing cell death (Sedlacek and Kucera 2010). The maximum reduction rate of $\mathrm{Cr}(\mathrm{VI})$ as well as growth of $O$. intermedium BCR400 at optimal AQS $(1 \mathrm{mM})$ in medium containing $100 \mathrm{mg} \mathrm{Cr}(\mathrm{VI}) / \mathrm{L}$ may be due to efficient relay of electrons from primary electron donor to AQS to $\mathrm{Cr}(\mathrm{VI})$ mediated through action of reductases. Rau et al. (2002) also observed highest reduction of azo dye amaranth in presence of $1 \mathrm{mM}$ AQS.

Intracellular quinone and chromate reductase activities of $O$. intermedium BCR400 induced in the presence of AQS

The intracellular quinone and chromate reductase activities in O. intermedium BCR400 grown in LB were found to be $0.0063 \pm 0.0010$ and $0.0042 \pm 0.0001 \mathrm{U} / \mathrm{mg}$, respectively (Table 4). The quinone and chromate reductase activity was found to increase in O. intermedium BCR400 grown in presence of $\mathrm{Cr}(\mathrm{VI})(100 \mathrm{mg} / \mathrm{L})$ or $1 \mathrm{mM}$ AQS. Furthermore, the extent of quinone reductase induction was found to be higher in cells grown in presence of AQS than in presence of $\mathrm{Cr}(\mathrm{VI})$; whereas the extent of chromate reductase induction was not profoundly influenced by $\mathrm{Cr}(\mathrm{VI})$ over AQS. It is noteworthy to mention here that the presence of $\mathrm{AQS}+\mathrm{Cr}(\mathrm{VI})$ synergistically influenced the level of intracellular chromate reductase and not quinone

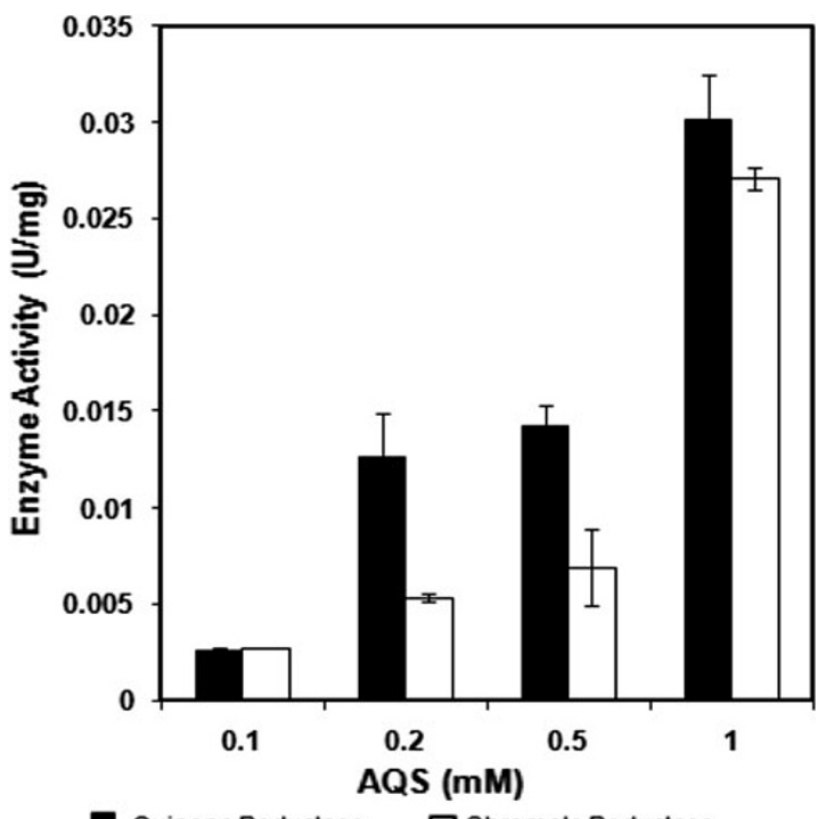

Quinone Reductase

Fig. 3 Quinone and chromate reductase activity $(\mathrm{U} / \mathrm{mg})$ of $O$. intermedium BCR400 grown in presence of increasing AQS concentrations $(0-1.0 \mathrm{mM})$

reductase. This suggests that $\mathrm{Cr}(\mathrm{VI})$ reduction in $O$. intermedium BCR400 may occur directly by chromate reductase as well as by reduced $\mathrm{AQS}\left(\mathrm{AQH}_{2} \mathrm{~S}\right)$ formed upon action of quinone reductase. Furthermore, both types of reductases seem to have relaxed substrate specificity; chromate reductase being more specific for $\mathrm{Cr}(\mathrm{VI})$, while quinone reductase being more specific for quinoid compounds (Puzon et al. 2002; Rau et al. 2002).

When $O$. intermedium BCR400 was grown in the presence of varying AQS concentration $(0.1-1 \mathrm{mM})$ the intracellular quinone and chromate reductase activities were found to increase from $0.0025 \pm 0.00019$ to $0.030 \pm 0.0024 \mathrm{U} / \mathrm{mg}$ protein and $0.0027 \pm 0.00002$ to $0.027 \pm 0.0005 \mathrm{U} / \mathrm{mg}$, respectively (Fig. 3). Furthermore, a strong and non-linear positive co-relation between the concentration of AQS and activities of both the enzymes $(\gamma>+90)$ was observed. This suggests the role of AQS in 

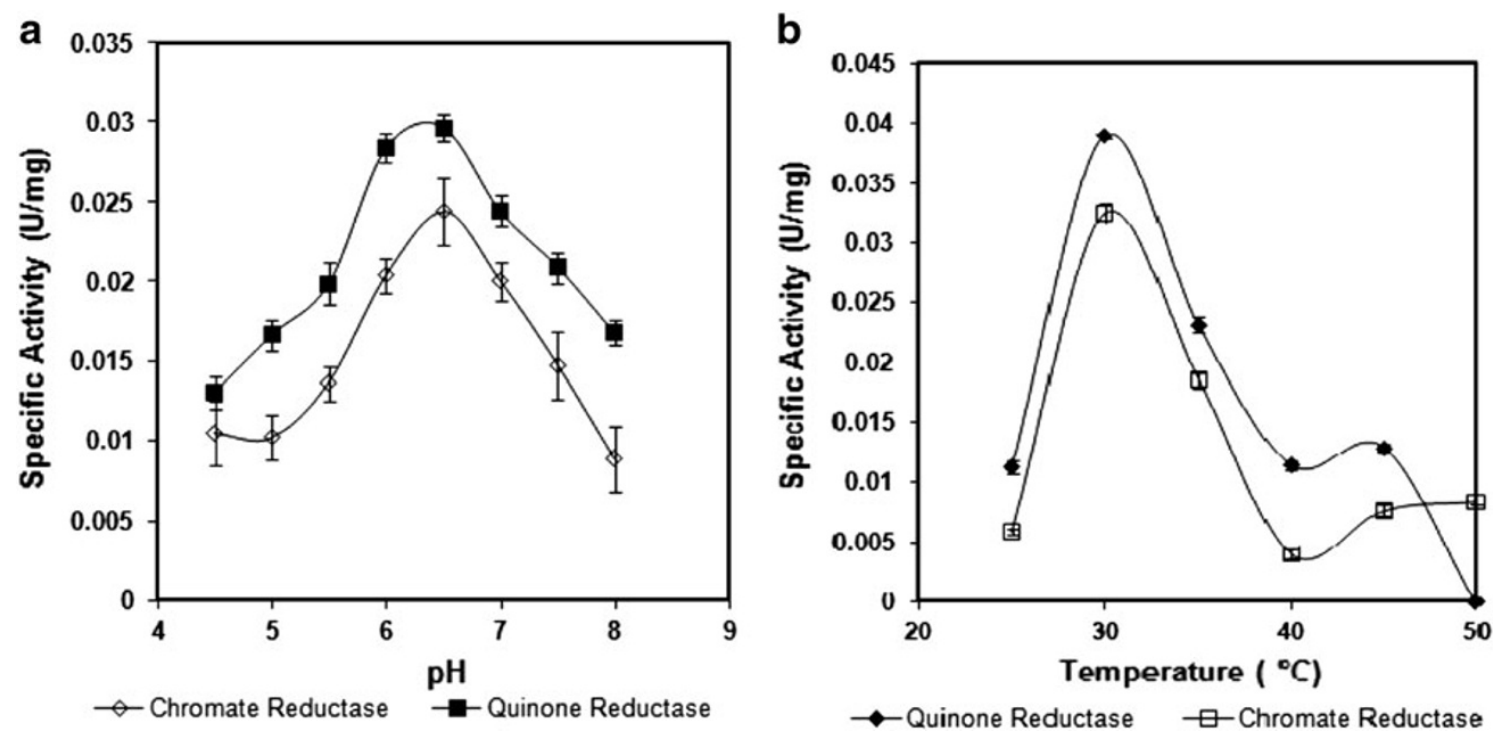

Fig. 4 Effect of $\mathrm{pH}(\mathbf{a})$ and temperature (b) on quinone and chromate reductase activity $(\mathrm{U} / \mathrm{mg})$ of $O$. intermedium BCR400

induction of quinone and chromate reductases in $O$. intermedium BCR400.

Both quinone and chromate reductase were found to follow similar activity profile over a $\mathrm{pH}$ range $5.0-8.5$ with maximum activities at $\mathrm{pH}$ 7.0. Also, the quinone and chromate reductase exhibited similar activity profile over a temperature range $25-45{ }^{\circ} \mathrm{C}$, with minor variation at $50{ }^{\circ} \mathrm{C}$ (Fig. 4). It is not possible to comment on these activities unless they are purified and characterized independently, if at all they exist as different enzymes.

Effect of temperature on AQS-mediated $\mathrm{Cr}(\mathrm{VI})$ reduction

Santos et al. (2004) observed that rate of Anthra Quinone Di-Sulphonate (AQDS)-mediated azo dye reduction was significantly higher in comparison to non-mediated azo dye reduction suggesting the role of AQDS in lowering the activation energy $(E a)$ of azo dye reduction. We monitored initial $\mathrm{Cr}(\mathrm{VI})$ reduction rate of $O$. intermedium $\mathrm{BCR} 400$ cells in presence and absence of $1 \mathrm{mM}$ AQS at different temperatures $\left(25-35{ }^{\circ} \mathrm{C}\right)$. The non-mediated $\mathrm{Cr}(\mathrm{VI})$ reduction rate of $O$. intermedium BCR400 increased from 0.005 to $0.02 \mathrm{~h}^{-1}$ with increase in temperature from 25 to $30{ }^{\circ} \mathrm{C}$ and remained constant thereafter with further increase in temperature up to $35{ }^{\circ} \mathrm{C}$. Similarly, the mediated $\mathrm{Cr}(\mathrm{VI})$ reduction rate increased from 0.007 to $0.034 \mathrm{~h}^{-1}$ with increase in temperature from 25 to $35{ }^{\circ} \mathrm{C}$ (Table 5).

Furthermore, the activation energy of AQS-mediated $\mathrm{Cr}(\mathrm{VI})$ reduction $\left(120.69 \mathrm{KJ} \mathrm{mol}^{-1}\right)$ was found to be 1.1-fold lower than non-mediated $\mathrm{Cr}(\mathrm{VI})$ reduction $\left(133.86 \mathrm{KJ} \mathrm{mol}^{-1}\right)$. Santos et al. (2004) observed that activation energy of AQS-mediated azo dye (reactive red 2)
Table 5 Effect of temperature on $\mathrm{Cr}(\mathrm{VI})$ reduction rate $\left(\mathrm{h}^{-1}\right)$ of $O$. intermedium BCR400 in presence (mediated) and absence (nonmediated) of $1 \mathrm{mM}$ AQS

\begin{tabular}{lll}
\hline Temperature $\left({ }^{\circ} \mathrm{C}\right)$ & \multicolumn{2}{l}{$\mathrm{Cr}(\mathrm{VI})$ reduction rate $\left(\mathrm{h}^{-1}\right)$} \\
\cline { 2 - 3 } & Non-mediated & Mediated \\
\hline 25 & $0.005 \pm 0.0001$ & $0.007 \pm 0.0015$ \\
30 & $0.020 \pm 0.0001$ & $0.022 \pm 0.0012$ \\
35 & $0.021 \pm 0.0002$ & $0.034 \pm 0.0011$ \\
\hline
\end{tabular}

reduction $\left(22.9 \mathrm{KJ} \mathrm{mol}^{-1}\right)$ by anaerobic sludge was 1.2 -fold lower than non mediated dye reduction $\left(27.9 \mathrm{KJ} \mathrm{mol}^{-1}\right)$ in anaerobic sludge.

There have been many studies on the role of redox mediators such as AQS, AQDS and Lawsone in bacterial azo dye reduction under anaerobic condition. Rau et al. (2002) proposed that mechanism for such redox mediator dependent reduction of azo dyes consist of two independent reaction steps: First, the quinones are enzymatically reduced to the corresponding hydroquinone (Ling et al. 2009; Rau and Stolz 2003) and second, the hydroquinones cleave the azo dyes in purely chemical reaction. Following the proposed mechanism by Rau et al. (2002), Ling et al. (2009) suggested that entire reaction rate depends on enzymatic reduction of redox mediators. Accordingly, the effectiveness of any mediator depends on the presence of membrane bound or intracellular reductase with mediator reducing ability.

Hence, a hypothetical model for AQS-mediated multistep $\mathrm{Cr}(\mathrm{VI})$ reduction by $O$. intermedium $\mathrm{BCR} 400$ has been proposed. In the first step, AQS may be reduced to $\mathrm{AQH}_{2} \mathrm{~S}$ (hydraquinone) by quinone reductase. In the second step, the $\mathrm{AQH}_{2} \mathrm{~S}$ reduces $\mathrm{Cr}(\mathrm{VI})$ by $2 \mathrm{e}^{-}$transfer, thereby 
reducing it to $\mathrm{Cr}(\mathrm{IV})$ in a purely redox chemical reaction. The direct reduction of $\mathrm{Cr}(\mathrm{VI})$ to $\mathrm{Cr}(\mathrm{IV})$ by $\mathrm{AQH}_{2} \mathrm{~S}$ would as well prevent ROS generation and thereby exerting protective effect on the growth of $O$. intermedium BCR400. The further reduction of $\mathrm{Cr}$ (IV) to $\mathrm{Cr}$ (III) may be catalysed by single e-transfer catalyzed by specific chromate reductase or non-specific reductases. The model is based on several lines of evidences:

1. The supplementation of AQS to nutrient growth medium amended with $\mathrm{Cr}(\mathrm{VI})$, not only had protective effect against toxicity due to $\mathrm{Cr}(\mathrm{VI})$ but also enhanced the rate of $\mathrm{Cr}(\mathrm{VI})$ reduction by $O$. intermedium $\mathrm{BCR} 400$.

2. Increase in both quinone and chromate reductase activity (U/mg protein) was observed in cell-free lysate prepared from $O$. intermedium BCR400 grown in presence of AQS or $\mathrm{Cr}(\mathrm{VI})+\mathrm{AQS}$.

3. The CFE of $O$. intermedium BCR400 grown in presence variable AQS concentration $(0-1 \mathrm{mM})$ displayed high, non-linear positive correlation between the concentration of AQS and activities of both quinone reductase and chromate reductase $(\gamma>+90)$.

\section{Conclusion}

The $O$. intermedium BCR400 isolated from chromiumcontaminated site reduced $100 \mathrm{mg} \mathrm{Cr}(\mathrm{VI}) / \mathrm{L}$ efficiently within $52 \mathrm{~h}$. The augmentation of $1 \mathrm{mM}$ AQS in the medium enhanced the $\mathrm{Cr}(\mathrm{VI})$ reduction efficiency of $O$. intermedium BCR400. The activation energy required for AQS mediated $\mathrm{Cr}(\mathrm{VI})$ reduction was found to be 1.1-fold lower than non-mediated $\mathrm{Cr}(\mathrm{VI})$ reduction by $O$. intermedium BCR400. Furthermore, AQS was found to induce both quinone and chromate reductase activities in cells of O. intermedium BCR400, which further exhibited similar activity profile over a $\mathrm{pH}$ range $4.5-8.0$ and temperature range $25-45{ }^{\circ} \mathrm{C}$. On the basis of results, it is proposed that AQS-mediated $\mathrm{Cr}(\mathrm{VI})$ reduction by $O$. intermedium BCR400 is a two step process, wherein the first step involves enzymatic reduction of $\mathrm{AQS}$ to $\mathrm{AQH}_{2} \mathrm{~S}$ and in second step $\mathrm{AQH}_{2} \mathrm{~S}$ reduces $\mathrm{Cr}(\mathrm{VI})$ to $\mathrm{Cr}(\mathrm{IV})$ in a purely chemical reaction. The $\mathrm{Cr}(\mathrm{IV})$ thus formed would be reduced to $\mathrm{Cr}(\mathrm{III})$ by cellular specific or non-specific enzymes. However, this hypothesis needs to be investigated using purified enzymes and sophisticated tools particularly required monitoring different valence forms of $\mathrm{Cr}$ produced during its reduction.

Acknowledgments HK acknowledges Department of Science \& Technology (DST), New Delhi for funding the project and BK is thankful to University Grants Commission (UGC), New Delhi, India for award of fellowship under 'UGC Research fellowships for meritorious students' scheme.
Open Access This article is distributed under the terms of the Creative Commons Attribution License which permits any use, distribution and reproduction in any medium, provided the original author(s) and source are credited.

\section{References}

Agarwal A, Kumar V, Pandey BD (2008) Remediation options for the treatment of electroplating and leather tanning effluent containing chromium-a review. Miner Process Extr Metall Rev 272:99-130

Bond DR, Lovley DR (2002) Reduction of Fe(III) oxide by methanogens in the presence and absence of extracellular quinones. Environ Microbiol 4:115-124

Branco R, Alpoim MC, Morais PV (2004) Ochrobactrum tritici strain 5bvI1-characterization of a $\mathrm{Cr}(\mathrm{VI})$ resistant and $\mathrm{Cr}(\mathrm{VI})$ reducing strain. Can J Microbiol 50:697-703

Cervantes C, Campos-Garcia J, Devars S, Gutierrez-Corona F, LozaTavera H, Torres Guzman JC, Moreno-Sanchez R (2001) Interaction of chromium with microorganisms and plants. FEMS Microbiol Rev 25:335-347

Clark DP (1994) Chromate reductase activity of Enterobacter aerogenes is induced by nitrite. FEMS Microbiol Lett 122:233-238

Costa M (1997) Toxicology and carcinogenicity of $\mathrm{Cr}(\mathrm{VI})$ in animal models and humans. Cr Rev Toxicol 27:431-442

Diaz MIR, Perez CD, Vargas E, Riveros-Rosas H, Campos-Garcia J, Cervantes C (2008) Mechanisms of bacterial resistance to chromium compounds. Biometals 21:321-332

Dinakarpandian D, Morrissette V, Chaudhary S, Amini K, Bennett B, Horn JDV (2004) An informatics search for the low molecular weight chromium binding peptide. BMC Chem Biol 4:1-7

Fredrickson JK, Kostandarithes HM, Li SW, Plymale AE, Daly MJ (2006) Reduction of $\mathrm{Fe}(\mathrm{III}), \mathrm{Cr}(\mathrm{VI}), \mathrm{U}(\mathrm{VI})$ and $\mathrm{Tc}(\mathrm{VII})$ by Deinococcus radiodurans R1. Appl Environ Microbiol 66: 2006-2011

Garbisu C, Alkorta I, Llama MJ, Serra JL (1998) Aerobic chromate reduction by Bacillus subtilis. Biodegradation 9:133-141

Gonzalez CF, Ackerley DF, Lynch SV, Matin A (2005) ChrR, a soluble quinone reductase of Pseudomonas putida that defends against $\mathrm{H}_{2} \mathrm{O}_{2}$. J Biol Chem 280:22590-22595

Gonzalez CF, Ackerley DF, Park CH, Matin A (2003) A soluble flavoprotein contributes to chromate reduction and tolerance by Pseudomonas putida. Acta Biotechnol 23:233-239

He Z, Gao F, Sha T, Hu Y, He C (2009) Isolation and characterization of a $\mathrm{Cr}(\mathrm{VI})$-reducing Ochrobactrum sp. strain $\mathrm{CSCr}-3$ from chromium landfill. J Hazard Mater 163:869-873

Ishibashi Y, Cerventes C, Silver S (1990) Chromium reduction in Pseudomonas putida. Appl Environ Microbiol 6:2268-2270

Kwak YH, Lee DS, Kim HB (2003) Vibrio harveyi nitroreductase is also a chromate reductase. Appl Environ Microbiol 69:4390-4395

Ling J, Hong LU, Jiti Z, Jing W (2009) Quinone mediated decolourization of sulfonated azo dyes by cells and cell extracts from Sphingomonas xenophaga. J Environ Sci 21:503-508

Liu G, Yang H, Wang J, Jin R, Zhou J, Lv H (2010) Enhanced chromate reduction by resting Escherichia coli cells in the presence of quinone redox mediators. Bioresour Technol 101:8127-8131

Losi ME, Amrhein C, Frankenberger WT (1994) Factors affecting chemical and biological reduction of hexavalent chromium in soil. Environ Toxic Chem 13:1727-1735

Lovley DR, Fraga JL, Blunt-Harris EL, Hayes LA, Phillips EJP, Coates JD (1998) Humic substance as a mediator for microbially catalyzed metal reduction. Acta Hydrochim Hydrobiol 26:152-157 
Lovley DR, Fraga JL, Coates JD, Blunt-Harris EL (1999) Humics as an electron donor for anaerobic respiration. Environ Microbiol 1:89-98

Lowry OH, Rosebroough NJ, Farr AL, Randall RJ (1951) Protein measurements with folin phenol reagents. J Biol Chem 193:265-275

Maithreepala RA, Doong R (2009) Transformation of carbon tetrachloride by biogenic iron species in the presence of Geobacter sulfurreducens and electron shuttles. J Hazard Mater 164:337-344

Mazoch J, Tesar R, Sedlacek V, Kucera I, Turanek J (2004) Isolation and biochemical characterization of two soluble iron (III) reductases from Paracoccus denitrificans. Eur J Biochem 271:553-562

McCullough J, Hazen T, Benson S, Blaine-Meyying F, Palmisano AC (1999) Bioremediation of metals and radionuclides.US Dept. of Energy, Office of Biological and Environmental Research, Germantown, MC 20874

Megharaj M, Avudainayagam S, Naidu R (2003) Toxicity of hexavalent chromium and its reduction by bacteria isolated from soil contaminated with tannery waste. Curr Microbiol 47:51-54

Myers CR, Carstens BP, Antholine WE, Myers JM (2000) Chromium (VI) reductase activity is associated with the cytoplasmic membrane of anaerobically grown Shewanella putrefaciens MR-1. J Appl Microbiol 88:98-106

Nishioka H (1975) Mutagenic activity of metal compounds in bacteria. Mutat Res 31:185-189

Ozdemir G, Ozturk T, Ceyhan N, Isler R, Cosar T (2003) Heavy metal biosorption by biomass of Ochrobactrum anthropi producing exopolysaccharide in activated sludge. Bioresour Technol 90:71-74

Puzon GJ, Petersen JN, Roberts AG, Kramer DM, Xun L (2002) A bacterial flavin reductase system reduces chromate to a soluble chromium (III)-NAD ${ }^{+}$complex. Biochem Biophys Res Commun 294:76-81

Rau J, Knackmuss HJ, Stolz A (2002) Effects of different quinoid redox mediators on the anaerobic reduction of azo dyes by bacteria. Environ Sci Technol 36:1497-1504

Rau J, Stolz A (2003) Oxygen- insensitive nitroreductases NfsA and $\mathrm{NfsB}$ of Escherichia coli function under anaerobic conditions as lawsone dependent azo reductases. Appl Environ Microbiol 69:3448-3455

Rehman A, Zahoor A, Muneer B, Hasnain S (2008) Chromium tolerance and reduction potential of a Bacillus sp. ev3 isolated from metal contaminated wastewater. Bull Environ Contam Toxicol 81:25-29
Saleh F, Parkerton TF, Lewis RV, Huang JH, Dickson KL (1989) Kinetics of chromium transformations in the environment. Sci Total Environ 86:25-41

Santos AB, Cervantes FJ, Lier JB (2004) Azo dye reduction by thermophilic anaerobic granular sludge and the impact of the redox mediator anthraquinone-2, 6-disulfonate (AQDS) on the reductive biochemical transformation. Appl Microbiol Biotechnol 64:62-69

Sedlacek V, Kucera I (2010) Chromate reductase activity of the Paracoccus denitrificans ferric reductase B (FerB) protein and its physiological relevance. Arch Microbiol 192:919-926

Shannon MJR, Unterman R (1993) Evaluating bioremediation: distinguishing fact from fiction. Ann Rev Microbiol 47:715-738

Shen H, Wang Y (1993) Characterization of enzymatic reduction of hexavalent chromium by Escherichia coli ATCC 33456. Appl Environ Microbiol 59:3771-3777

Sultan S, Hasnain S (2006) Characterization of an Ochrobactrum intermedium strain STCr-5 manifesting high level $\mathrm{Cr}(\mathrm{VI})$ resistance and reduction potential. Enzyme Microb Technol 39:833-888

Sultan S, Hasnain S (2007) Reduction of toxic hexavalent chromium by Ochrobactrum intermedium strain SDCr-5 stimulated by heavy metals. Bioresour Technol 98:340-344

Suzuki T, Miyata N, Horitsu H, Kawai K, Takamizawa K, Tai Y, Okazaki M (1992) NAD(P)H-dependent chromium(VI) reductase of Pseudomonas ambigua G-1: a $\mathrm{Cr}(\mathrm{V})$ intermediate is formed during the reduction of $\mathrm{Cr}(\mathrm{VI})$ to $\mathrm{Cr}(\mathrm{III})$. J Bacteriol 174:5340-5345

Tamura K, Dudley J, Nei M, Kumar S (2007) MEGA4: molecular evolutionary genetics analysis (MEGA) software version 4.0. Mol Biol Evol 24:1596-1599

Thacker U, Madamwar D (2005) Reduction of toxic chromium and partial localization of chromium reductase activity in bacterial isolate DM1. World J Microbiol Biotechnol 21:891-899

Wang P, Mori T, Toda K, Ohtake H (1990) Membrane-associated chromate reductase activity from Enterobacter cloacae. J Bacteriol 172:1670-1672

Wang Y, Wu C, Wang X, Zhou S (2009) The role of humic substances in the anaerobic reductive dechlorination of 2 , 4-dichlorophenoxyacetic acid by Comamonas korensis strain CY01. J Hazard Mater 164:941-947

Williams JW, Silver S (1984) Bacterial resistance and detoxification of heavy metals. Enzyme Microb Technol 6:530-537

Zee FPVD, Cervantes FJ (2009) Impact and application of electron shuttles on the redox (bio) transformation of contaminants: a review. Biotechnol Adv 27:256-277 